\title{
Estimation of Water Quality Parameters of Rawal Lake and Its Associated Tributaries
}

\author{
Akhtar Hussain Lashari ${ }^{1,2}$, Naeem Ali ${ }^{3 *}$, Muhammad Mohiuddin ${ }^{4}$, Jawad Ali ${ }^{1}$, \\ Sana Ullah ${ }^{8}$, Safdar Ali Ujjan ${ }^{5}$, Khadim Hussain Memon ${ }^{5}$, Khalid Hussain Rind ${ }^{6}$, \\ Saeed Siyal', Wajid Rashid ${ }^{8}$ \\ ${ }^{1}$ School of Environment, Beijing Normal University, Beijing 100875, China \\ ${ }^{2}$ Department of Education, Sukkur IBA University, Airport Road, Sukkur 65200, Pakistan \\ ${ }^{3}$ Department of Microbiology, Quaid-i-Azam University, Islamabad 45320, Pakistan \\ ${ }^{4}$ Department of Forestry and Rangeland management, Kohsar University, Murree 47150, Pakistan \\ ${ }^{5}$ Department of Zoology, Shah Abdul Latif University, Khairpur Mirs 66111, Pakistan \\ ${ }^{6}$ Department of Molecular Biology and Genetics, Shaheed Benazir Bhutto University, \\ Shaheed Benazirabad 67450, Pakistan \\ ${ }^{7}$ Department of Business Administration and Information Studies, Greenwich University, Karachi 75500, Pakistan \\ ${ }^{8}$ Department of Environmental and Conservation Sciences, University of Swat, Mingora 19130, Pakistan
}

Received: 21 November 2020

Accepted: 25 June 2021

\begin{abstract}
Globally, the rapid growth of the population over the past century has put enormous pressure on freshwater resources. Pakistan, as a developing country, also faces a freshwater crisis. Rawal Lake, an essential freshwater reservoir near Pakistan's capital, has been showing signs of deterioration for the past few years. Therefore, a brief study was planned to analyze the water quality of the lake and the associated recharge streams. Twelve physical and chemical parameters were selected along with the total bacterial and Escherichia coli count. Five sampling points were selected for water sampling. Results showed that the Mallpur stream significantly has higher $\mathrm{pH}$, total suspended solids, and total dissolved solids values than the other sampling points and was not within the permissible limits of the World Health Organization. In the case of total bacterial count and Escherichia coli count, except Spillway, water samples showed higher concentrations than the permissible limits of world health organization. However, the mineral content such as Calcium, Magnesium, Nitrogen, Potassium, Chloride, and sulphate concentration at all sampling points are within the permissible limits of the world health organization's drinking water standard. Results also showed that the water sampled from the Korang River tributary has more deterioration in physicochemical properties as well
\end{abstract}

*e-mail: naeemali95@gmail.com 
as in total bacterial count than the Mallpur tributary. Due to the deterioration of the water quality parameter, it is suggested that Rawal Lake water is not suitable for human consumption.

Keywords: Rawal Lake, water quality, electric conductivity, bacterial contamination, freshwater demand

\section{Introduction}

Water is one of nature's most precious gifts to humanity through clean drinking water, which is necessary for the survival of all living organisms [1]. Certainly, water and Gross Domestic Product (GDP) per capita have a secure link. Nevertheless, some analysts predict that by 2025 , more than half the world's population will confront water-based vulnerability $[2,3]$. Agricultural activities urbanization, population growth, and industrialization have reduced the drinking water supply. The result is the discharge of wastewater into lakes, estuaries, and rivers without any treatment $[4,5]$. Surface water resources have played a pivotal role in Pakistan. The significant environmental influences are climatic, hydrological and, geological since these affect the quantity and quality of existing water [6]. The population has generated over the last century, increasing the pressure on existing water resources. When demand continues to grow, the quality of the world of water available will, in the long term, not meet the needs of more people [7]. Nearly two billion people in 80 countries worldwide are unable to make good use of water, which is an essential requirement for life $[8,9]$. The manipulation of water resources is chiefly anthropogenic [10] and some natural activities [11]. Retaining the quality and accessibility of freshwater resources is one of Pakistan's foremost environmental and social challenges [9]. Pollution and water quality degradation interfere with the important and legal use of water at local, regional and international levels [12]. Pollution from the inflows has degraded the water quality of rivers, natural lakes, and reservoirs in developing countries [13]. Lakes are the principal source of freshwater for people [14].

Rawal Lake is an artificial reservoir that meets twin city's water needs such as Islamabad and Rawalpindi $[15,16]$. This reservoir currently faces many problems, such as silting, discharge of effluents, environmental degradation, water pollution, and overfishing [17]. The villages which are situated near Rawal Lake are Bani Gala Bhara Kahu, Mallpur, and Noorpur Shahan consists of about 5000 residents [18]. These villages' population has grown at a very high rate that affects water quality [16]. This includes the dumping of untreated sewage and solid waste in tributaries of river Korang. About 170 poultry ranches are having about 360 poultry sheds in the catchment area. No adequate treatment arrangement has been made for poultry waste. Murree Hills, Chattar park, and several other beautiful places in the catchment area of Rawal Lake attract tourists, which is another source of pollution [19]. Water quality monitoring has become a major concern in evaluating the lake's condition and the longterm trend for future lake management [20]. According to United Nations Environment Programme (UNEP) in 2003, dams oblige to function as an evident means for supplying freshwater resources that contribute to socio-economic development through providing drinking water [21]. Therefore, the quality of dam water should be monitored and lead to an acceptable standard to ensure safe water that enters water treatment intake. Hence, the water of Rawal Lake is not drinkable to the Rawalpindi, Islamabad, and other dependents. This paper aims to assess the physicochemical properties of Rawal lake and its associated tributaries that recharge Rawal Lake.

\section{Material and Methods}

\section{Study Area}

Rawal Lake is situated in Islamabad, Pakistan, across Korang River at a distance of about $10 \mathrm{~km}$ from Rawalpindi at the latitude of $33^{\circ} 42^{\prime} \mathrm{N}$ and longitude $73^{\circ} 07^{\prime} \mathrm{E}$ with a total catchment area of approximately $268 \mathrm{~km}^{2}$ [22], as shown in Fig. 1.

\section{Water Sampling and Preservation}

Water sampling was carried out at five different sites of the study area, as shown in Fig. 2. From each site, five samples were collected and recorded as their average value. Two streams feed the Rawal Lake: Mallpur tributary (S1) and Korang River tributary (S2). From each tributary, five water samples were collected. Water sampling was carried out at three different sites of Rawal Lake such as the main Pushta (S3), Center (S4), and spillway (S5). The water sampling was conducted for the whole week. All water samples were collected in $1.5 \mathrm{~L}$ plastic bottles. Before the collection of water samples, all bottles were washed 3 times with sample water. A discrete water sampling technique was applied at $20-25 \mathrm{~cm}$ depth at each sampling site. The samples were stored and preserved in an icebox between 2 to $10^{\circ} \mathrm{C}$ to reduce a change in water chemistry tests for physicochemical properties, Escherichia coli (E. coli) count, and total bacterial count.

\section{Water Analysis}

The $\mathrm{pH}$ value of water was determined by a $\mathrm{pH}$ meter applying the method as described by Mcclean (1982). Electrical Conductivity (EC) was monitored by the EC meter. Total solids of the water samples were 


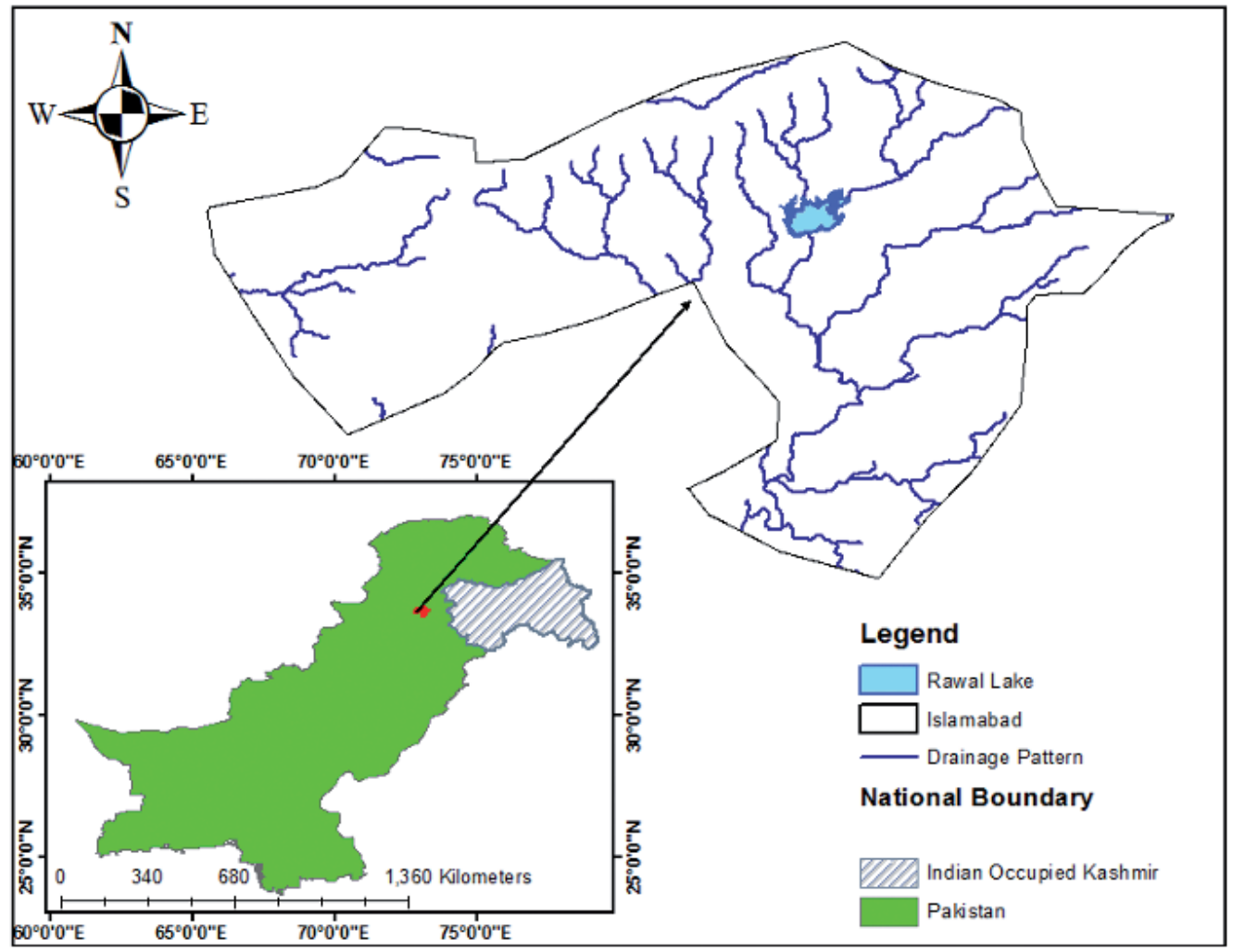

Fig. 1. Map of Pakistan showing the area of study.

determined by taking $100 \mathrm{ml}$ of water in a pre-weighted china dish, and water was evaporated by using a hot plate. It was then cooled in desiccators and weighed again [23]. Chloride $\left(\mathrm{Cl}^{-1}\right)$ content and alkalinity of water samples were determined by a methodology adopted in previous work [24, 25]. The hardness of the water samples was determined by a standard procedure [26]. In water, Sulphate $\left(\mathrm{SO}_{4}^{-2}\right)$ is usually

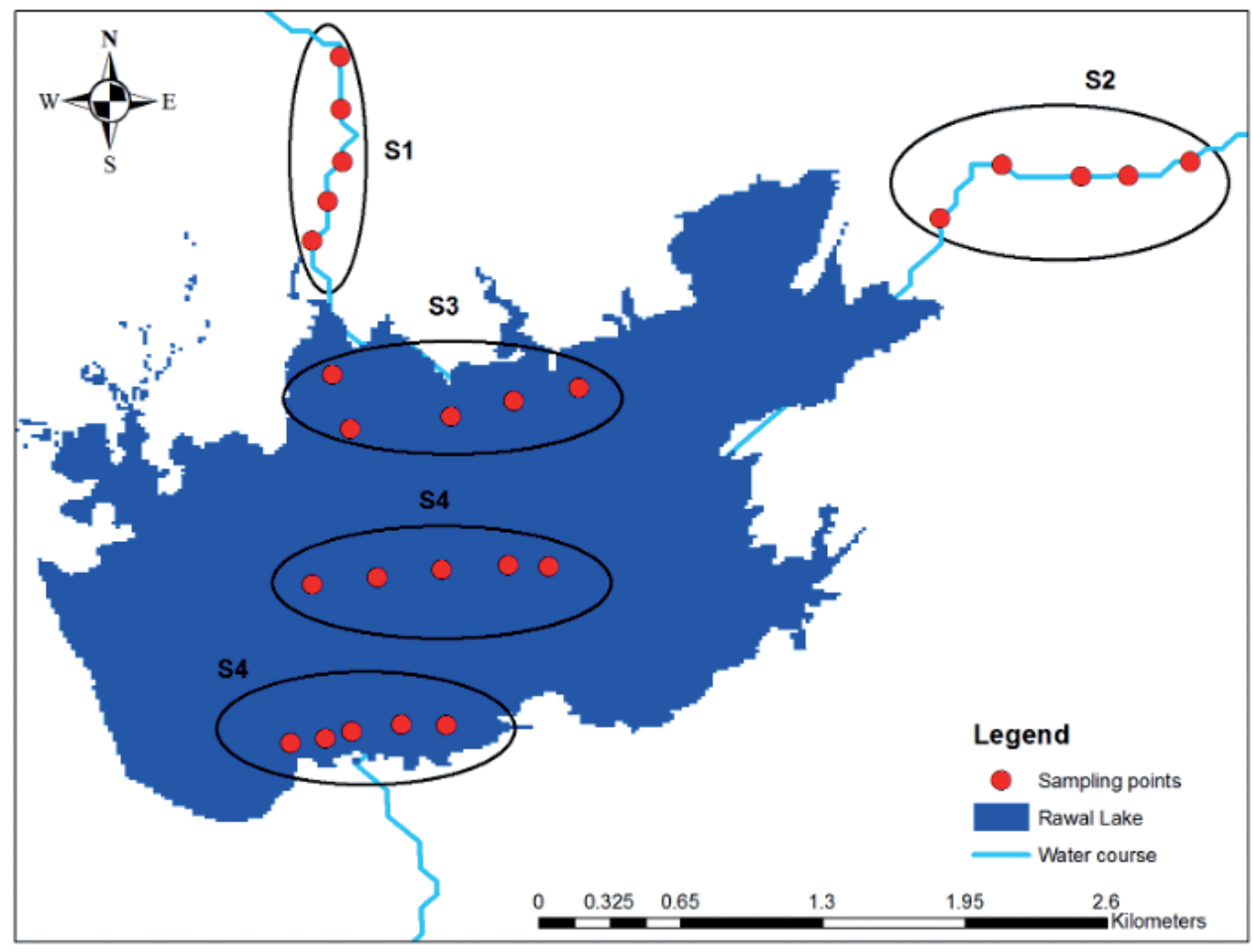

Fig. 2. Water sampling point within and outside of the Rawal Lake. 
associated with Magnesium (Mg), and Calcium (Ca). $\mathrm{SO}_{4}^{-2}$ content in sample water was converted into Barium Sulphate $\left(\mathrm{BaSO}_{4}\right)$ as described by a researcher in previous work [27]. The concentration of Total Suspended Solids (TSS) in water samples was ascertained by the weight difference of pretreated $\left(400^{\circ} \mathrm{C}\right.$ for two hours) filters before and after the filtration of water. $\mathrm{Ca}, \mathrm{Mg}$, Sodium $(\mathrm{Na})$, and Potassium $(\mathrm{K})$ content in the water was determined by Atomic Absorption Spectrometry (AAS)[28].

\section{Total Bacterial Count and E. coli Count}

For the determination of total bacterial count and E. coli count, the pour plate method was used. A dilute sample of $1 \mathrm{ml}$ was put into an empty sterile plate with the help of a pipette. Then chrogen media was poured into it and was mixed with the diluted sample. Chrogen was not sloped larger than the petri dish border and kept for 10 minutes so that the media become entirely gelled and the surface was "smooth a glass". Finally, it was inverted and kept in an incubator for 24-48 hours at $35^{\circ} \mathrm{C}$. Colonies were counted and recorded [29].

\section{Statistical Analysis}

Data for physicochemical parameters of water samples were presented as mean values and analyzed using descriptive analysis. For the mean difference, Least Significant Difference (LSD) test was used. Before investigating the seasonal effect on water quality parameters, the sampling was divided into four fixed seasons: spring-19 (March, April, and May), summer-19 (June, July, and August), autumn-19 (September, October, and November), and winter-19-2020 (December, January, and February).

\section{Results and Discussion}

The present study was carried out to determine the physicochemical properties of Rawal Lake and its associated streams. LSD showed that the $\mathrm{pH}$ of the S2 $(9.26 \pm 0.06)$ was significantly higher than other samples. Similarly, the $\mathrm{pH}$ of the water collected from tributaries (S1 \& S2) was higher than that of the lake water. Domestic sources such as the use of detergents and bleaching agents significantly influence the $\mathrm{pH}$ of the streams. Previous studies argued that the water of the stream that feeds Rawal Lakes are significant contributors of pollutants [30]. Total Dissolved Solids (TDS) of water samples were collected from different points (S1S5) ranges between $435 \pm 2.88$ to $210 \pm 4.61 \mathrm{mg} / \mathrm{L}$. LSD showed that the S2 point was characterized by significantly higher TDS values than other points (Table 1). Similarly, the TSS of water samples collected ranges between $39.3 \pm 2.9$ to $124.32 \pm 8 \mathrm{mg} \mathrm{L}^{-1}$. LSD test showed that TSS at S1 was significantly higher than other points. Moreover, TSS values at all sampled points were not within the permissible limits of the World Health Organization (WHO) drinking water standard. This is due to the presence of poultry waste that not only brought a change in the $\mathrm{pH}$ of water but also affected the TDS and TSS [31]. TSS reduces not only the light penetration in the water bodies that reduced the gross productivity of the freshwater ecosystems [32] but also makes it unfit for drinking and other commercial purposes. Primary sources of TDS can be attributed to agriculture runoff, leaching of soil contaminants which may cause certain diseases in man and cattle [33]. Probably the water flow in rivers and streams influenced TDS. Also, at the point of discharge of stream water, a notable increase was observed for the mean value of $\mathrm{pH}$, TDS, and TSS [34].

Hard water is not a health hazard, but a higher value of hardness can impair the quality of water. Alkalinity and hardness values of all samples were very low and within prescribed limits of WHO. Mg content in water samples ranges between $45.3 \pm 1.4$ to $77.6 \pm 0.88 \mathrm{mg} \mathrm{L}^{-1}$. The analysis revealed that the S2 point had higher Mg content as compared to other points. The potassium content in water varied between $1.8 \pm 0.057$ to $3.5 \pm 0.34 \mathrm{mg} \mathrm{L}^{-1}$. The $\mathrm{Na}, \mathrm{K}$, and $\mathrm{Ca}$ (as Calcium Carbonate $\left(\mathrm{CaCO}_{3}\right)$ was within the permissible limit of WHO. Calcium was significantly higher, like

Table 1. Physicochemical properties of the water sampled at different locations.

\begin{tabular}{|c|c|c|c|c|c|c|c|c|}
\hline & Parameters & $\mathrm{pH}$ & $\mathrm{EC}$ & TDS & TSS & $\mathrm{Mg}$ & $\mathrm{Na}$ & $\mathrm{K}$ \\
\hline & Units & - & $\mathrm{uS} \mathrm{cm}{ }^{-1}$ & \multicolumn{5}{|c|}{$\mathrm{mg} \mathrm{L}^{-1}$} \\
\hline \multirow{6}{*}{$\begin{array}{l}\text { Sampling } \\
\text { Sites }\end{array}$} & $\mathrm{S} 1$ & $8.20 \pm 0.07^{\mathrm{b}}$ & $586 \pm 5.29^{\mathrm{b}}$ & $411.6 \pm 7.6^{\mathrm{b}}$ & $124.32 \pm 8.0^{\mathrm{a}}$ & $71 \pm 0.57^{b}$ & $29.3 \pm 0.88^{b}$ & $3.5 \pm 0.34^{\mathrm{a}}$ \\
\hline & S2 & $9.27 \pm 0.06^{\mathrm{a}}$ & $639.3 \pm 4.66^{\mathrm{a}}$ & $435 \pm 2.88^{\mathrm{a}}$ & $95 \pm 5.1^{\mathrm{b}}$ & $77.6 \pm 0.88^{\mathrm{a}}$ & $37.6 \pm 1.45^{\mathrm{a}}$ & $3.26 \pm 0.12^{\mathrm{a}}$ \\
\hline & S3 & $7.25 \pm 0.04^{c}$ & $415.3 \pm 7.21^{\mathrm{c}}$ & $225 \pm 2.8^{\mathrm{d}}$ & $57.6 \pm 5.36^{c}$ & $59 \pm 1.52^{\mathrm{c}}$ & $18 \pm 0.57^{\mathrm{d}}$ & $2.3 \pm 0.15^{\mathrm{bc}}$ \\
\hline & $\mathrm{S} 4$ & $7.07 \pm 0.04^{\mathrm{d}}$ & $415.6 \pm 4.3^{\mathrm{c}}$ & $210 \pm 4.6^{\mathrm{d}}$ & $44.3 \pm 2.3^{\mathrm{cd}}$ & $48.3 \pm 0.8^{\mathrm{d}}$ & $23.5 \pm 1.04^{\mathrm{c}}$ & $2.5 \pm 0.11^{\mathrm{b}}$ \\
\hline & S5 & $7.09 \pm 0.04 \mathrm{c}^{\mathrm{d}}$ & $378.6 \pm 5.20^{\mathrm{d}}$ & $248.6 \pm 6.3^{\mathrm{c}}$ & $39.3 \pm 2.9^{\mathrm{d}}$ & $45.3 \pm 1.4^{\mathrm{d}}$ & $21.4 \pm 0.83^{\mathrm{c}}$ & $1.8 \pm 0.057^{\circ}$ \\
\hline & WHO & $6.5-9.20$ & NGV & 1000 & 5 & 150 & 200 & 75 \\
\hline
\end{tabular}

* Means in the same column followed by the same superscripts are not significant at $p<0.05$. 


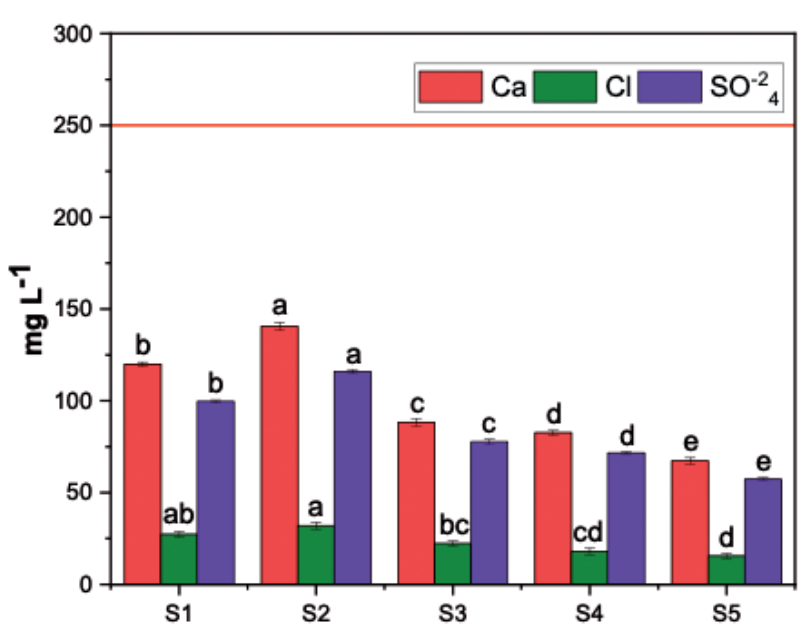

Fig. 3. Calcium, chloride, sulphate concentration at different location of water samples.

*redline shows the WHO permissible limit

$140.6 \pm 2.3 \mathrm{mg} \mathrm{L}^{-1}$ at $\mathrm{S} 2$, as compared to other points. Similarly, the calcium content was higher at sources and decreased gradually towards the discharge point of the lake (S5; Spillway) (Fig. 3). LSD test showed that samples at $\mathrm{S} 2$ have a higher concentration of $\mathrm{SO}_{4}^{-2}$ as compared to other sampling points (Fig. 3). $\mathrm{SO}_{4}^{-2}$ normally occurs naturally in water and has a concentration ranging from a few to several thousand milligrams per liter [35]. The chloride content in water samples was between $15.5 \pm 1.32$ to $32 \pm 1.7 \mathrm{mg} \mathrm{L}^{-1}$. LSD test revealed that the sample collected at S2 showed a significantly higher concentration than other samples (Fig. 3). Whereas, $\mathrm{SO}_{4}^{-2}$ concentration was within the recommended value of drinking water standard limitation of $\mathrm{WHO} . \mathrm{Cl}^{-}$concentrations are often very high in urban streams, especially during the winter because of runoff activities [36].

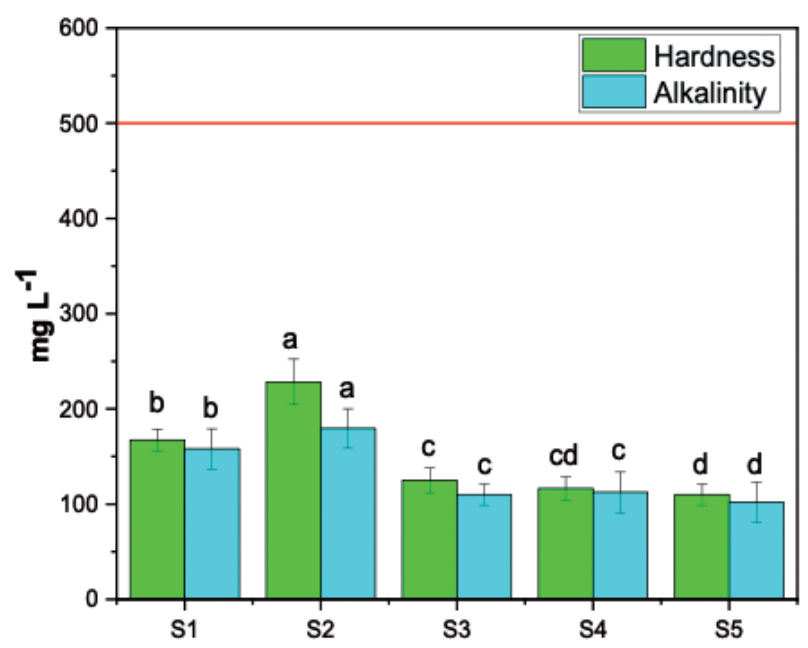

Fig. 4. Hardness and alkalinity concentration at different location of water samples.
LSD test also revealed a significantly higher concentration of all $\mathrm{Mg}, \mathrm{Na}, \mathrm{Ca}$, and $\mathrm{K}$ at the $\mathrm{S} 2$ sampling point. Poultry waste has a higher concentration of these minerals [37]. EC also showed a significant variation amongst the two streams as well as within the lake water. S2 points exhibited significantly higher EC as compared to other sampling points (Table 1). It might be related to the influence of runoff on the concentration levels of elements in water [38]. The results showed that the hardness of water ranged between $39.33 \pm 2.9$ to $124.33 \pm 8.08 \mathrm{mg} \mathrm{L}-1$. Water samples collected from the S1 point have significantly higher total hardness $(124.33 \pm 8.08 \mathrm{mg} \mathrm{L}-1)$ as compared to other points (Fig. 4). The total alkalinity value of all samples was within permissible limits of WHO standards. Its value ranges from $102 \pm 1.15$ to $179.3 \pm 0.88 \mathrm{mg} \mathrm{L}-1$. (Fig. 4).

In all water samples collected, the total bacterial count and E. coli were higher than the permissible limits of WHO (Fig. 5). The highest bacterial count was found at S2 while the highest $E$. coli was observed at S4 as compared to other points. Because the poultry sheds are directly disposed off along the stream which led to higher E. coli and bacterial count [39]. This may have resulted in many diseases [40] such as cholera, diarrhea, hepatitis, typhoid, and dysentery [41]. The highest count of E. coli bacteria showed fecal contamination and is considered to be a risk for human health [42]. S4 points have the lowest bacterial count. It may be due to the movement of water at this place as water discharges regularly from the spillway. Therefore, it is recommended that domestic wastewater, as well as industrial wastewater, should be collected and treated before disposed off in the tributaries of the Rawal lake. Seasonal and continuous monitoring of the physicochemical properties of Rawal lake is recommended. Clean and pure water filter pumps should be installed for the public so that healthy water could easily be accessible.

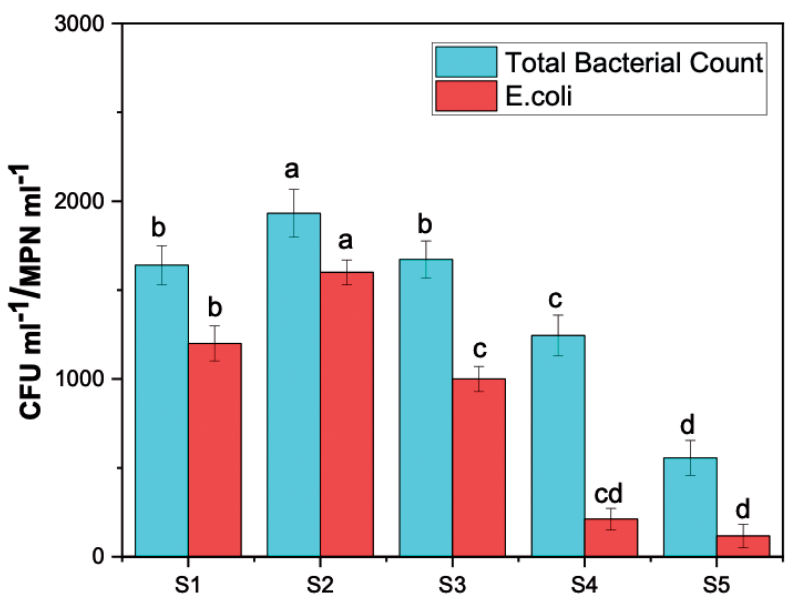

Fig. 5. Total bacterial and E. coli count at different location of water samples

*WHO permissible limit for the total bacterial count is $<100$ while for $E$. coli is $<1.1$ 


\section{Conclusions}

The preliminary results obtained in this study show that some of the water quality parameters such as $\mathrm{pH}$, TSS, and TDS are quite high and beyond the permissible limits of WHO at stream S2. Whereas, total bacterial and E. coli count, all water samples collected from Rawal dam's different locations were significantly high than the WHO drinking water standards. Based on these observations, it is concluded that Rawal Lake water could be useful for agricultural purposes but should not be used for drinking purposes. The water sample collected from S2 (Korang River) was highly contaminated because of the presence of a large number of poultry farms. The water sample collected from the Mallpur stream was found contaminated mainly due to high population density. The water sample of Rawal Lake was also not drinkable due to its recreational aspect.

\section{Acknowledgments}

This research was supervised by Dr. Naeem Ali and the authors thank him for his financial assistance. The author also thanked the cooperation of the Rawal Lake administration in Islamabad.

\section{Conflict of Interest}

The author declares no conflict of interest.

\section{References}

1. UMAR M., KAMBAI J., MOHAMMED I., OKO J., OBAFEMI A., MURTALA I., AJIYA K., YAYA A., ABDULKARIM I., AKAFYI D.J.I.J.o.P.R. Bacteriological quality assessment and antibiogram profile of bacteria associated with sachet drinking water sold at Zaria, Northern Nigeria. 13, 2019.

2. PAKMEHR S., YAZDANPANAH M., BARADARAN M. How collective efficacy makes a difference in responses to water shortage due to climate change in southwest Iran. Land Use Policy. 99, 104798, 2020.

3. ZEHTABIYAN-REZAIE N., ALVANDIFAR N., SAFFARAVAL F., MAKKIABADI M., RAHMATI N., SAFFAR-AVVAL M. A solar-powered solution for water shortage problem in arid and semi-arid regions in coastal countries. Sustainable Energy Technologies and Assessments. 35, 11, 2019.

4. PREISNER M., NEVEROVA-DZIOPAK E., KOWALEWSKI Z. Mitigation of eutrophication caused by wastewater discharge: A simulation-based approach. Ambio. 2020.

5. BAGUMA D., HASHIM J.H., ALJUNID S.M., LOISKANDL W. Safe-water shortages, gender perspectives, and related challenges in developing countries: The case of Uganda. Science of The Total Environment. 442, 96, 2013.
6. YU D., XIE P., DONG X., SU B., HU X., WANG K., XU $\mathrm{S}$. The development of land use planning scenarios based on land suitability and its influences on eco-hydrological responses in the upstream of the Huaihe River basin. Ecological Modelling. 373, 53, 2018.

7. KAHLOWN M., TAHIR M., RASHEED H. Fifth water quality monitoring report, 2005-2006. Pakistan Council of Research in Water Resources (PCRWR). 133, 2008.

8. SHAMSUZZOHA M., RASHEDUZZAMAN M., GHOSH R.C. Building Resilience for Drinking Water Shortages through Reverse Osmosis Technology in Coastal Areas of Bangladesh. Procedia Engineering. 212, 559, 2018.

9. HANJRA M.A., QURESHI M.E. Global water crisis and future food security in an era of climate change. Food Policy. 35 (5), 365, 2010.

10. KUWAYAMA Y., OLMSTEAD S.M., WIETELMAN D.C., ZHENG J. Trends in nutrient-related pollution as a source of potential water quality damages: A case study of Texas, USA. Science of The Total Environment. 724, 137962, 2020.

11. FRICK C., VIERHEILIG J., NADIOTIS-TSAKA T., IXENMAIER S., LINKE R., REISCHER G.H., KOMMA J., KIRSCHNER A.K.T., MACH R.L., SAVIO D., SEIDL D., BLASCHKE A.P., SOMMER R., DERX J., FARNLEITNER A.H. Elucidating fecal pollution patterns in alluvial water resources by linking standard fecal indicator bacteria to river connectivity and genetic microbial source tracking. Water Research. 184 (1), 116132, 2020.

12. AZIZULLAH A., KHATTAK M.N.K., RICHTER P., HÄDER D.-P. Water pollution in Pakistan and its impact on public health - A review. Environment International. 37 (2), 479, 2011.

13. TIBEBE D., KASSA Y., MELAKU A., LAKEW S. Investigation of spatio-temporal variations of selected water quality parameters and trophic status of Lake Tana for sustainable management, Ethiopia. Microchemical Journal. 148, 374, 2019.

14. SALEEM F., AZIM M.K., MUSTAFA A., KORI J.A., HUSSAIN M.S. Metagenomic profiling of fresh water lakes at different altitudes in Pakistan. Ecological Informatics. 51 (2), 73, 2019.

15. AHAD K., MOHAMMAD A., MEHBOOB F., SATTAR A., AHMAD I. Pesticide residues in rawal lake, Islamabad, Pakistan. Bulletin of environmental contamination and toxicology. 76 (3), 463, 2006.

16. IQBAL J., SHAH M.H., AKHTER G. Characterization, source apportionment and health risk assessment of trace metals in freshwater Rawal Lake, Pakistan. Journal of Geochemical Exploration. 125, 94, 2013.

17. CHANDIO S.H., AHMED S.M., SALEEM W., NAEEM S., BHUTTO S., SANJRANI M. Assessment of PhysicalChemical Parameters of Water along the Catchment Areas of Rawal Dam Islamabad, Pakistan. Eurasian Journal of Science \& Engineering. 4, 13, 2019.

18. EPA P. Report On Rawal Lake Catchment Area Montoring Operation. Pakistan Environmental Protection Agency, Ministry of Environment. 2004.

19. GHUMMAN A.R. Assessment of water quality of Rawal Lake by long-time monitoring. Environmental monitoring and assessment. 180 (4), 115, 2011.

20. SEIFERT-DÄHNN I., FURUSETH I.S., VONDOLIA G.K., GAL G., DE EYTO E., JENNINGS E., PIERSON D. Costs and benefits of automated high-frequency environmental monitoring - The case of lake water 
management. Journal of Environmental Management. 285, 112108, 2021.

21. SHUHAIMI-OTHMAN M., AHMAD A., MUSHRIFAH I., LIM E.J.P.o.T. Seasonal influence on water quality and heavy metals concentration in Tasik Chini, Peninsular Malaysia. 300, 2007.

22. AFTAB N. Haphazard colonies polluting Rawal Lake, Daily Times Monday, March 01. 2010.

23. GOHAIN M., PRAJAPATI D., SANDHU J.S.J.S. A novel $\mathrm{Cu}$-catalysed three-component one-pot synthesis of dihydropyrimidin-2 (1H)-ones using microwaves under solvent-free conditions. 2004 (2), 235, 2004.

24. ACHARYA G., HATHI M., PATEL A.D., PARMAR K. Chemical properties of groundwater in bhiloda taluka region, north Gujarat, India. E-Journal of Chemistry. 5 (4), 792, 2008.

25. PATIL P., SAWANT D., DESHMUKH R. Physicochemical parameters for testing of water-a review. International Journal of Environmental Sciences. 3 (3), 1194, 2012.

26. MITRA P.P., PESARAN B. Analysis of Dynamic Brain Imaging Data. Biophysical Journal. 76 (2), 691, 1999.

27. PRAHARAJ S., NATH S., GHOSH S.K., KUNDU S., PAL T. Immobilization and recovery of Au nanoparticles from anion exchange resin: resin-bound nanoparticle matrix as a catalyst for the reduction of 4-nitrophenol. Langmuir. 20 (23), 9889, 2004.

28. IEGGLI C.V.S., BOHRER D., DO NASCIMENTO P.C., DE CARVALHO L.M., GARCIA S.C. Determination of sodium, potassium, calcium, magnesium, zinc, and iron in emulsified egg samples by flame atomic absorption spectrometry. Talanta. 80 (3), 1282, 2010.

29. NAGHILI H., TAJIK H., MARDANI K., RAZAVI ROUHANI S.M., EHSANI A., ZARE P. Validation of drop plate technique for bacterial enumeration by parametric and nonparametric tests. Veterinary research forum: an international quarterly journal. 4 (3), 179, 2013.

30. AHMED R. Impact of environmental pollution in Rawalpindi-Islamabad. Sanitation and Water for All. Islamabad, Pakistan. 157, 1998.

31. ADEWALE P., VITHANAGE L.N., CHRISTOPHER L. Optimization of enzyme-catalyzed biodiesel production from crude tall oil using Taguchi method. Energy Conversion and Management. 154, 81, 2017.

32. SHINDE S., PATHAN T., RAUT K., MORE P., SONAWANE D. Seasonal variations in physico- chemical characteristics of Harsool-Savangi dam, District Aurangabad, India. The ecoscan. 4 (1), 37, 2010.

33. GHARIBI H., SOWLAT M.H., MAHVI A.H., MAHMOUDZADEH H., ARABALIBEIK H., KESHAVARZ M., KARIMZADEH N., HASSANI G. Development of a dairy cattle drinking water quality index (DCWQI) based on fuzzy inference systems. Ecological Indicators. 20, 228, 2012.

34. RABEE A., ALTAHIR B., ALDHAMIN A. Seasonal Variations of Some Ecological Parameters in Tigris River Water at Baghdad Region, Iraq. Journal of Water Resource and Protection. 3, 262, 2011.

35. CHOUDHARY R., RAWTANI P., VISHWAKARMA M. Comparative study of drinking water quality parameters of three manmade reservoirs ie Kolar, Kaliasote and Kerwa Dam. Current World Environment. 6 (1), 145, 2011.

36. KAUSHAL S.S., GROFFMAN P.M., LIKENS G.E., BELT K.T., STACK W.P., KELLY V.R., BAND L.E., FISHER G.T. Increased salinization of fresh water in the northeastern United States. Proceedings of the National Academy of Sciences. 102 (38), 13517, 2005.

37. SMITH J.A., TODD P.E.J.A.E.R. Reconciling conflicting evidence on the performance of propensity-score matching methods. 91 (2), 112, 2001.

38. BIDDOCCU M., FERRARIS S., OPSI F., CAVALLO E. Long-term monitoring of soil management effects on runoff and soil erosion in sloping vineyards in Alto Monferrato (North-West Italy). Soil and Tillage Research. 155, 176, 2016.

39. MASTOI G.M., SHAH S.G.S., KHUHAWAR M.Y. Assessment of water quality of Manchar Lake in Sindh (Pakistan). Environmental monitoring and assessment. 141 (3), 287, 2008.

40. HABTESELASSIE M., BISCHOFF M., BLUME E., APPLEGATE B., REUHS B., BROUDER S., TURCO R. Environmental controls on the fate of Escherichia coli in soil. Water, air, and soil pollution. 190 (4), 143, 2008.

41. SADEGHI G., MOHAMMADIAN M., NOURANI M., PEYDA M., ESLAMI A. Microbiological quality assessment of rural drinking water supplies in Iran. Journal of Agriculture \& Social Sciences. 3 (1), 31, 2007.

42. DJUIKOM E., NJINE T., NOLA M., SIKATI V., JUGNIA L. Microbiological water quality of the Mfoundi River watershed at Yaoundé, Cameroon, as inferred from indicator bacteria of fecal contamination. Environmental Monitoring and assessment. 122 (3), 171, 2006. 